\title{
Harry Potter and The Philosopher's Stone: A Systemic Functional Analysis
}

\author{
Chyi Ann Ong ${ }^{1} \&$ Genevieve F. Dipolog-Ubanan ${ }^{1}$ \\ ${ }^{1}$ Faculty of Social Sciences \& Liberal Arts, UCSI University, Kuala Lumpur, Malaysia \\ Correspondence: Chyi Ann Ong, Faculty of Social Sciences \& Liberal Arts, UCSI University, Kuala Lumpur, \\ Malaysia.
}

Received: October 5, 2021

Accepted: December 20, $2021 \quad$ Online Published: January 17, 2022

doi:10.5539/ells.v12n1p56

URL: https://doi.org/10.5539/ells.v12n1p56

\begin{abstract}
Gender-stereotyped roles of female and male characters are common in literature. Seeing that Harry Potter series has gained much popularity especially among children and teenagers, this qualitative paper attempts to investigate to what extent the author, Rowling (1997), confirms or challenges the gender stereotypes in the portrayal of the main male and female characters through her lexical (words) and grammatical (nouns, verbs, adjective and adverbs) choices. Halliday's transitivity system is used to examine the lexis and structures that Rowling chose to describe the characters in her novel. Several scenes which contain descriptions about the main male and female characters were analyzed. Analysis of the excerpts from the novel showed that both the male and female main characters are portrayed with either feminine or masculine roles.
\end{abstract}

Keywords: transitivity, SFL, Harry Potter, masculinity/femininity, processes and participants

\section{Introduction}

Socialization is one of the essential processes where children acquire certain roles and behaviors, including gender roles. Other than parents' and teachers' intentional or unintentional efforts in shaping the beliefs about gender roles in the children, mass media such as books, television, radio, etc. to which children are exposed every day, plays an important role as well in spreading beliefs of the roles that they are expected to play in the society. These shared beliefs often take the form of oversimplified gender role stereotypes (Kortenhaus \& Demarest, 1993).

According to Berk (2003, p. 520), gender stereotypes are "widely-held beliefs about characteristics deemed appropriate for males and females", which reflect gender roles in everyday behavior. Block explained the concept of gender role as "a constellation of qualities an individual understands to characterize males and females in his or her culture" (1973, p. 512). Similarly, Golombok and Fivush (1994, p. 3) stated that "gender role includes the behaviors and attitudes considered appropriate for males or females in a particular culture." From these statements, one can deduce that gender stereotypes consist of multiple domains, including personality traits, physical characteristics, occupations, role behaviors, social relations, attitudes and interests (Berk, 2003; Block, 1973; Golombok \& Fivush, 1994). Golombok and Fivush (1994) further commented that these different aspects of gender stereotypes are interrelated: a female is expected to have certain personalities (gentle, sensitive, emotional), possess certain physical characteristics (weak, graceful), and hold certain nurturing-type of occupation (nurse, kindergarten teacher).

According to a British national daily newspaper, The Guardian (Flood, 2011, May 6), it was found that the number of male main characters in literary genre far exceeds female characters, pointing to "symbolic annihilation of women and girls". Besides, in children's literature, male characters are generally portrayed with characteristics of strongly aggressive, initiative, competent, etc. while female characters showed many passive characteristics, such as dependent, lacking competence, needing help and protection, etc. (Frasher \& Walker, 1972). Females are also perceived to be nurturant, dependent, and submissive, i.e., females exhibit traits that are viewed as less desirable or useful by the society (Dino, Barnett, \& Howard, 1984; Spence \& Helmreich, 1980). The analysis of the portrayal of male and female characters in children's literature (Anderson \& Hamilton, 2005; Oskamp, Kaufman, \& Wolterbeek, 1996), as well as in the illustrated picture books that preschoolers love to read (Barnett, 1986; Vu, 2008; Weitzman, Eifler, Hokada, \& Ross, 1972) reveal these gender stereotypes.

The main corpus of this paper is the first book of Harry Potter series-Harry Potter and the Philosopher's Stone. 
As what the fictional character Professor McGonagall had predicted about Harry Potter's future that "every child in our world will know his name!", the series about the young wizard has gained much popularity especially among children and teenagers. Tsatsa (2013) suggested that one plausible explanation why the Harry Potter series has become extremely popular among young and adult readers would be that the author of the series, Rowling (1997), has made her readers feel comfortable with or empathetic towards the recognizable characters in the novel. From the time the first novel was published in 1997, the best-selling series has been translated into 73 languages and sold more than 450 million copies (USA Today, 2014). Thus, one can argue that what the author J. K. Rowling has written in the series about men and women and their roles can greatly influence her readers' viewpoints to such an extent that it may even shape the children's beliefs on gender roles. Therefore, this paper would investigate to what extent Rowling confirms or confronts the gender stereotypes in the portrayal of the main male and female characters as reflected in her lexical and grammatical choices when describing these characters or the events surrounding them.

To discover whether Rowling's writing reflected gender stereotypes or not, three questions are designed which are listed as follows:

1) How are the main male and female characters being portrayed in the novel?

2) How are the grammatical processes and participants being used to describe the male and female main characters?

3) Are the gender stereotypes being promoted or challenged by Rowling's (1997) choices of words?

\section{Related Literature and Theories}

In this section, the theories that this paper are based on are explained, including the notion of gender stereotypes, John Stephen's Description of Masculinity and Femininity (1996), and Halliday's Systemic Functional Grammar and transitivity framework $(1970,1994)$. In addition, various studies from different genres looking into gender stereotypes are explored in order to present the results of past researches.

\subsection{Related Literature}

Studies on gender stereotypes in different genres of literary works revealed male characters being portrayed as engaging in more practical actions and playing more participant roles than female characters (Barnett, 1986; Gallardo, 2006; Gharbavi \& Mousavi, 2012), while female characters being portrayed as more emotional (Anderson \& Hamilton, 2005; Barnett, 1986) or timid (Oskamp, Kaufman, \& Wolterbeek, 1996) and engaging in stereotypical domestic chores or activities (Dickman \& Murnen, 2004)

There have been studies conducted on Harry Potter series to examine the prevalence of gender stereotypes in this literary work. In her study, Tsatsa (2013) analyzed the scenes, where the three main characters interacted with each other while performing their roles in everyday activities, using Stephens' (1996) schema for masculinity and femininity, which introduces dichotomies like inner strength/outer beauty, violent/non-violent, unemotional/emotional, protective/vulnerable, competitive/sharing and independent/dependent. Her findings revealed that the three main characters showed signs of possessing both female and male characteristics.

Stephens (1996, as cited in Tsatsa, 2013) constructed a schema for masculinity and femininity. According to Stephens, "socially desirable" males and females conform to the stereotypes attributed to them in order to be considered appropriate, in which masculine traits are generally viewed as more superior than the feminine ones. If a female challenges the stereotypes and shows signs of masculinity, she is often being compelled to revert back to the norm (1996; as cited in Tsatsa, 2013). The archetypal traits of male and female are shown as follows: 


\begin{tabular}{|ll|}
\hline Male characteristics & Female characteristics \\
Strong & Beautiful \\
Unemotional & Non-violent \\
Aggressive/Authoritarian & Emotional \\
Transgressive & Submissive \\
Competitive & Obedient \\
Rapacious & Sharing \\
Protective & Caring \\
Powerful & Vulnerable \\
Player & Powerless \\
Independent & Prize \\
Active & Dependent \\
Analytical & Passive \\
Rational & Synthesizing \\
\hline
\end{tabular}

Figure 1. Stephens' descriptions of masculinity and femininity (1996, p. 18)

\subsection{Halliday's Systemic Functional Linguistics (SFL)/Systemic Functional Grammar (SFG)}

Halliday's Systemic-Functional Linguistics (SFL) is a theory that centers on the notion of language function. SFL places the function of language as central to its analysis, investigating what language does and how language does it. (http://www.isfla.org/Systemics/definition.html)

Systemic functional grammar (SFG) is a model of grammar developed after SFL. The term "systemic" refers to the view of language as a network of interconnected systems, or interrelated sets of choices to produce meaning. The term "functional" indicates that the approach is concerned with practical uses to which language is put.

The functional approach to grammar essentially equates meaning with function. According to Bloor and Bloor (2004), there are three kinds of functions in SFG referred to as the three meta-functions:

- The interpersonal meta-function refers to the structural options in expressing interpersonal meanings. Terms associated with this meta-function include Mood and Mood types, Appraisal, Modality, and Modal Adjuncts, among others.

- The experiential (representational) meta-function refers to the linguistic resources that are used in representing the world, whether factual or imaginary, as well as for referring entities in the world and the ways in which those entities interact with one another. Terms associated with experiential meta-function include Process, Participant, Circumstance, Transitivity Patterns, and Ergativity, among others.

- The textual meta-function refers to the ways speakers/writers organize their message. This is concerned with how the text is structured as a message. Terms used in this meta-function include Theme and Rheme, Thematic Structures, Cohesion, Coherence, and Conjunctions, among others.

SFG presents a view of language in terms of both structure (grammar) and words (lexis). The term "lexicogrammar" describes this combined approach. In this paper, the focus is on the lexical and grammatical choices of Rowling (1997) in her description of the three main characters.

To sum up, in this paper, SFG is used to examine the gender stereotypes in Harry Potter as it is a useful approach in exploring and analyzing the representational functions of the language of the novel. The "founder" of SFG, MAK Halliday (1970, 1994), has argued that language is a social semiotic system, and that semantics and lexico-grammar are interrelated. He classified the functional areas of language that serve the social and 
personal needs into three continuously interconnected meta-functions: experiential, interpersonal and textual. In this paper, the excerpts would be explored under the lens of the experiential meta-function to help in revealing Rowling's ideologies and representational meanings in terms of her choices of descriptive words and grammatical structures in Harry Potter.

\subsubsection{Transitivity Framework}

Halliday's transitivity framework is chosen to analyze the interaction between the main characters in Harry Potter. The processes ('verbs'), participants ('nouns' as subjects or objects) and circumstances ('adverbs') that Rowling used to describe the characters are studied in order to encode the representational or experiential meanings of the clauses from the chosen excerpts. Transitivity is the lexico-grammatical realization of the ideational (experiential) meta-function proposed by Halliday (1994), which is based on the process type realized by the main verb in the clause. The structure of this framework can be separated into:

- A lexical verb - referring to a type of Process

- Subject and Object(s) / Complements realized by Noun Phrases-in active voice, representing the Participants corresponding to the Process referred to in the verb

- Adverbials or Adjuncts-representing Circumstances

Halliday (1994) had suggested a total of six process types, three of which are main processes (material, mental and relational) and the other three are minor process types (existential, verbal, and behavioral), which can be placed on the boundaries of the main process types. Each process is associated with its own participants, the entities involved in the process. In other words, the role of participants is dependent upon the main verb in a clause corresponding to the type of process. Each of the processes and their participants are described as follows (Halliday, 1994):

- Material: represents what is occurring in the world, what actions and events are taking place. Actor is the participant who causes or initiates the action while Goal is the receiver of the action.

- Mental: represents how people are perceiving, feeling and thinking. The one who feels or thinks is known as Senser.

- Relational: relates to participant roles Token and Value, as well as possessor and possessed, representing the state of the things which exist and what relations they have to each other. This process involves Carrier and Attribute, where carrier is identified by reference to the attribute. Other roles in relational process are Possessor and Possessed, which is identified by the verb "has".

- Existential (located between material and relational processes): represents what exists in the world, by which phenomena of all kinds are simply recognized to 'be' - to exist, or to happen. Existent is the only participant in this process, and is usually identified by an empty Subject "There".

- Verbal (located between relational and mental processes): represents how people are communicating or expressing their perceptions, feelings and thoughts. The typical participant roles are Sayer and Recipient, where Sayer is the one who speaks and Recipient is the one who receives the message.

- Behavioral (located between mental and material processes): represents the outer manifestations of the inner workings of the mind, the acting out of processes of consciousness and physiological states. Behaver is the only participant being involved in this process.

Of these six processes, only the three main processes are studied, namely; material, mental, and relational. The purpose of analyzing material processes is to reveal who (either the male main character or the female main character) is described by the author as the 'agent' or 'doer' of the action (the Actor) and 'patient' or 'receiver' of the action (the Goal), in order to discover who is the character that is presented as active or receptive. As for mental processes, the rationale behind is to find out who is depicted as the one who feels and thinks, and also to see whether the male or women main characters are depicted to experience stereotypical feelings. Lastly, analyzing relational processes could help to determine the different attributes associated to the male and female main characters as Carriers.

\section{Methodology}

\subsection{Research Design}

A qualitative research design is used in this paper. Rowling's lexical and grammatical choices are examined in order to find out whether she has reinforced gender stereotypes in her novel or not. The SFG's transitivity framework by Halliday (1994) is adopted to examine the processes, participants and circumstances (the 
grammatical choices) found in the novel.

\subsection{Corpus}

The corpus of this paper is the first book of Harry Potter series - Harry Potter and the Philosopher's Stone. Published in 1997, it is regarded as the best-selling book series which has been translated into 73 languages and sold more than 450 million copies (USA Today, 2014). Hence, this book has been chosen for the study.

\subsection{Sampling Method}

Purposeful sampling is used in this paper. Excerpts which contained scenes depicting the three main characters interacting with each other as well as descriptions of their physical attributes or characteristics are extracted and examined to find out whether the lexical and grammatical choices reflect gender stereotypes or not.

\subsection{Data Collection and Analysis}

After identifying and isolating the scenes to be studied, the clauses are numbered and the process, participants and circumstances found in the clauses are examined by using the transitivity framework. The number of processes and the different types of participants associated to the main male and female characters are counted. Also, the attributes ('adjectives') being used to describe the main male and female characters are listed down and tabulated according to the descriptors introduced by Stephen (1996). Finally, the ideologies behind Rowling's representations of genders are discussed, and some conclusions based on the data and discussion are given.

\section{Research Findings and Discussion}

\subsection{Portrayal of the Main Characters According to Male or Female Traits}

The male and female's traits in each scenario extracted from the novel were classified according to Stephens' (1996) descriptions of femininity and masculinity as shown in Table 1.

Table 1. Analysis of the characteristics of the main characters in each scenario

\begin{tabular}{|c|c|c|}
\hline Scenario & How the Characters Were Portrayed & Examples Extracted from the Scenarios \\
\hline 1 & $\begin{array}{l}\text { - Harry: not strong; powerless; vulnerable; } \\
\text { passive }\end{array}$ & ...because of all the times Dudley had punched him on the nose (L6\&7) \\
\hline 2 & - $\quad$ Harry: powerless; vulnerable; passive & $\begin{array}{l}\text { Aunt Petunia had been trying to force him into a revolting old sweater of } \\
\text { Dudley's (L10\&11) }\end{array}$ \\
\hline 3 & $\begin{array}{ll}\text { - } & \text { Harry: passive } \\
\text { - } & \text { Hermione: active; competitive; aggressive } \\
\text { - } & \text { Ron: passive }\end{array}$ & $\begin{array}{l}\text { He waved his wand, but nothing happened. (L1) } \\
\text { I've learned all our course books by heart, of course (L6\&7) }\end{array}$ \\
\hline 4 & $\begin{array}{l}\text { - } \quad \text { Hermione: aggressive; obedient; competitive } \\
\text { - } \quad \text { Ron: emotional }\end{array}$ & $\begin{array}{l}\text { You haven't been fighting, have you? You'll be in trouble before we even get } \\
\text { there! (L3\&4) } \\
\text { "Scabbers has been fighting, not us," said Ron, scowling at her (L4\&5) }\end{array}$ \\
\hline 5 & $\begin{array}{l}\text { - } \quad \text { Harry: powerless } \\
\text { - } \quad \text { Hermione: competitive }\end{array}$ & $\begin{array}{l}\text { He'd never been more nervous, never (L7) } \\
\text {... except Hermione Granger, who was whispering very fast about all the } \\
\text { spells she'd learned (L5\&6) }\end{array}$ \\
\hline 6 & $\begin{array}{l}\text { - Harry: powerless; transgressive } \\
\text { - } \quad \text { Hermione: competitive; active; powerless; } \\
\text { obedient }\end{array}$ & $\begin{array}{l}\text { "I don't know, sir," said Harry (L7) } \\
\text { He ignored Hermione's hand (L8) }\end{array}$ \\
\hline 7 & $\begin{array}{l}\text { - Harry: protective; aggressive; violent } \\
\text { - } \quad \text { Hermione: aggressive; obedient; powerless }\end{array}$ & $\begin{array}{l}\text { "or I'll knock you off that broom!” (L13\&14) } \\
\text { "Madam Hooch told us not to move - you'll get us all into trouble." } \\
\text { (L4\&5) }\end{array}$ \\
\hline 8 & $\begin{array}{l}\text { - } \quad \text { Harry: transgressive; authoritarian } \\
\text { - } \quad \text { Hermione: aggressive; obedient } \\
\text { - } \quad \text { Ron: transgressive; violent; aggressive }\end{array}$ & $\begin{array}{l}\text { "And it's really none of your business," (L8) } \\
\text {... and you mustn't go wandering around the school at night (L5\&6) } \\
\text { "Throw it away and punch him on the nose," (L1\&2) }\end{array}$ \\
\hline 9 & $\begin{array}{l}\text { - } \quad \text { Harry: transgressive; authoritarian } \\
\text { - } \quad \text { Hermione: aggressive; competitive; } \\
\text { powerless; dependent }\end{array}$ & $\begin{array}{l}\text { "Come on," he said to Ron. (L5) } \\
\text { "Now what am I going to do?" she asked shrilly. (L16) } \\
\text { "You've got some nerve - " said Ron loudly. (L22) }\end{array}$ \\
\hline 10 & $\begin{array}{ll}\text { - } & \text { Ron: transgressive; emotional } \\
\text { - } & \text { Harry: vulnerable; active; intuitive } \\
\text { - } & \text { Hermione: vulnerable; passive; analytical } \\
\text { Ron: vulnerable; passive }\end{array}$ & $\begin{array}{l}\text { "This way!" Harry mouthed to the others (L5\&6) } \\
\text { "Malfoy tricked you," Hermione said to Harry. He was never going to meet } \\
\text { you - Filch knew someone was going to be in the trophy room, Malfoy } \\
\text { must have tipped him off." (L18-20) }\end{array}$ \\
\hline 11 & $\begin{array}{l}\text { - Harry: unemotional } \\
\text { - } \quad \text { Hermione: emotional; obedient; aggressive }\end{array}$ & $\begin{array}{l}\text { "I thought you weren't speaking to us?" said Harry. (L3\&4) } \\
\text { Hermione marched away with her nose in the air. (L5) }\end{array}$ \\
\hline
\end{tabular}




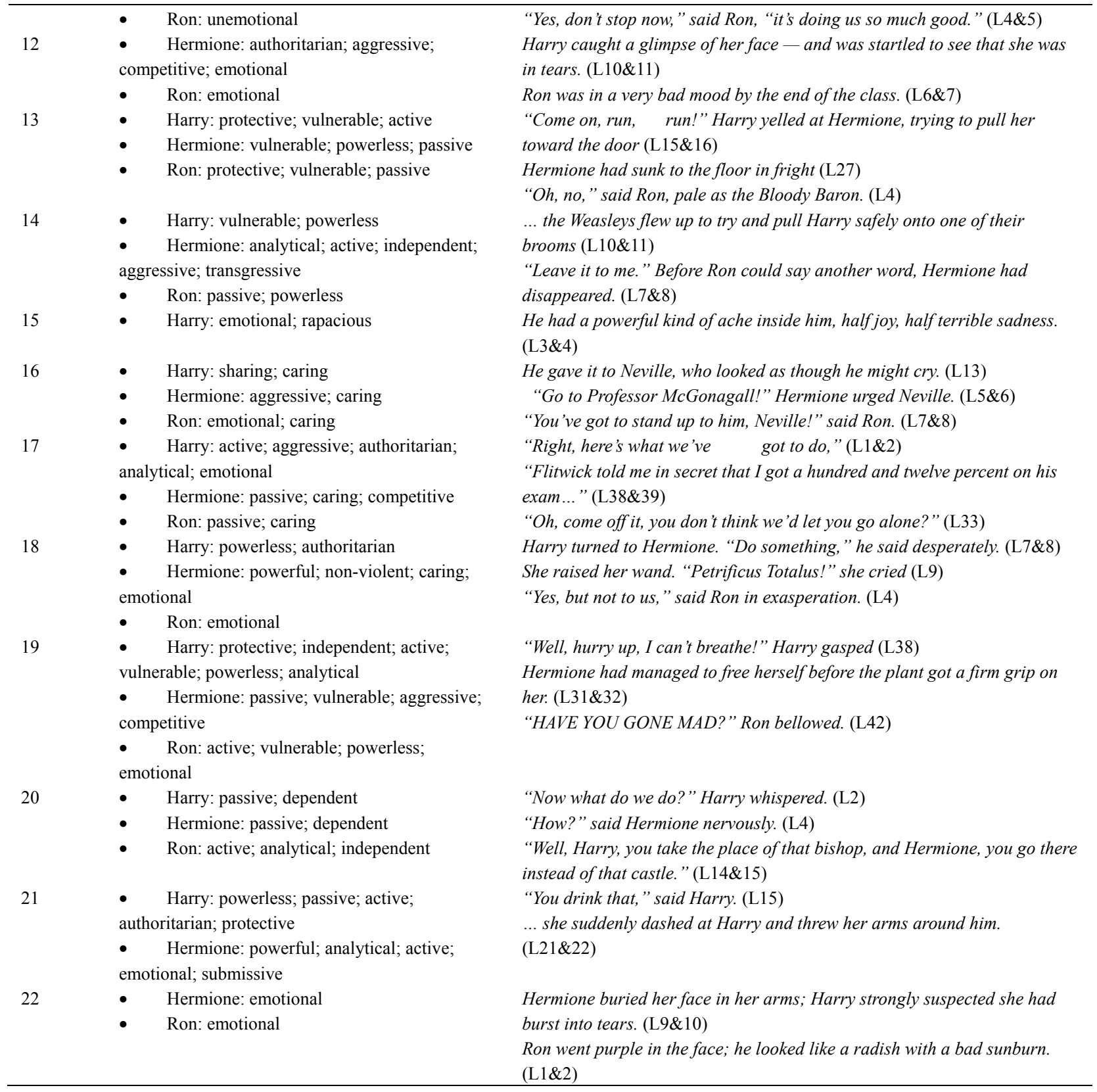

\subsection{Processes and Participants Involved in the Scenarios}

Only the three main processes, i.e., Material, Mental and Relational process, which involved the three main characters were studied. In other words, Verbal, Behavioral, Existential, as well as processes realized by objects and the characters other than the main ones were not included. The processes and participants involved in each scenario were analyzed accordingly (please refer to Appendix A II) and the occurrences realized by each character were counted as shown below: 
Table 2. Comparison of the occurrences of the processes among the characters

\begin{tabular}{llllll}
\hline Characters & Material & $\begin{array}{l}\text { Material } \\
\text { (Goal) }(\%)\end{array}$ & $\begin{array}{l}\text { Mental } \\
(\text { Senser) }(\%)\end{array}$ & $\begin{array}{l}\text { Mental } \\
\text { (Phenomenon) (\%) }\end{array}$ & $\begin{array}{l}\text { Relational } \\
(\text { Carrier) }(\%)\end{array}$ \\
\hline Harry & 43.02 & 40 & 66.67 & 11.11 & 56.25 \\
Hermione & 36.05 & 40 & 16.67 & 44.44 & 25 \\
Ron & 20.93 & 20 & 16.67 & 44.44 & 18.75 \\
Total & $86(100)$ & $25(100)$ & $24(100)$ & $9(100)$ & $16(100)$ \\
\hline
\end{tabular}

\subsection{Lexical Choices Used by Rowling (1997)}

There is always a reason why certain words were used than the others. It is interesting to see how different ideological meanings can be revealed by examining the word choices chosen by the author. According to Fairclough (1995, p. 58), "representations and recontextualizations of social practice, the identities of writers and readers or the relationship between writer and reader" could be uncovered through the analysis of any sentence in a text.

Among the four types of content words, i.e., nouns, verbs, adjectives and adverbs, only the adjectives and adverbs associated with the main characters were studied as the nouns (participants) and verbs (processes) were covered in the previous section. Adjective refers to a class of words which act as the modifiers of nouns and pronouns while adverbs are the modifiers of verbs, primarily describing the features or qualities of the words that are being modified (Crystal \& McLachlan, 2004).

Concepts that are denotatively similar can be connotatively different. In other words, words that have similar meanings can have different moods, depending on the different attitudes that are associated with them generally, whether favorable or unfavorable, which in turn evoke a positive or negative affective tone. For instance, in a study conducted by Staats and Staats (1958, as cited in Jacobson, 1979), it was found that names that are associated with positive words (e.g., happy) were rated as being more pleasant than those associated with neutral words (e.g., chair), while the latter names were rated as being more pleasant than those associated with negative words (e.g., ugly). In relation to this, the extracted adjectives and adverbs were classified into positive, negative or neutral connotations, based on the values associated with them in general.

The analysis of adjectives and adverbs were tabulated below (the words that acts as an adjective or an adverb in a phrase were italicized):

Table 3. Adjectives Associated with the Characters in Each Scenario

\begin{tabular}{|c|c|c|c|c|}
\hline \multirow[t]{2}{*}{ Scenario } & \multirow[t]{2}{*}{ Character } & \multicolumn{3}{|l|}{ Adjectives } \\
\hline & & Positive & Negative & Neutral \\
\hline 1 & Harry & & skinny & $\begin{array}{l}\text { small; thin face; knobby knees; } \\
\text { black hair; bright green eyes }\end{array}$ \\
\hline 3 & Ron & & & stunned \\
\hline 4 & Hermione & & said in a sniffy voice & \\
\hline 5 & Harry & & Harry's heart gave a horrible jolt; nervous & \\
\hline \multirow[t]{5}{*}{6} & Harry & & stumped & \\
\hline & Hermione & & desperate to start proving that she wasn't a & \\
\hline & & & dunderhead; quivering hand; her hand stretching & \\
\hline & & & toward the dungeon ceiling & \\
\hline & Ron & & stumped & \\
\hline 9 & Hermione & & interfering; like an angry goose & \\
\hline 10 & Harry & & horror-struck & \\
\hline 11 & Hermione & & angry & \\
\hline \multirow[t]{2}{*}{12} & Hermione & & a nightmare & \\
\hline & Ron & & & looked a bit uncomfortable \\
\hline \multirow[t]{3}{*}{13} & Harry & very brave & very stupid & \\
\hline & Hermione & & a high, petrified scream & \\
\hline & Ron & & pale as the Bloody Baron & \\
\hline 14 & Ron & & grey-faced & \\
\hline 17 & Hermione & & in a small voice & \\
\hline 21 & Harry & amazed & embarrassed & \\
\hline 22 & Ron & & $\begin{array}{l}\text { went purple in the face; like a radish with a bad } \\
\text { sunburn }\end{array}$ & \\
\hline
\end{tabular}


Table 4. Adverbs associated with the characters in each scenario

\begin{tabular}{|c|c|c|c|c|}
\hline \multirow[t]{2}{*}{ Scenario } & \multirow[t]{2}{*}{ Character } & \multicolumn{3}{|l|}{ Adverbs } \\
\hline & & Positive & Negative & Neutral \\
\hline 5 & Harry & & anxiously & \\
\hline \multirow[t]{2}{*}{6} & Harry & & & quietly \\
\hline & Hermione & & $\begin{array}{l}\text { stretched her hand as high into the air as it would go without } \\
\text { her seat }\end{array}$ & \\
\hline \multirow[t]{3}{*}{9} & Harry & & & sharply \\
\hline & Hermione & & shrilly & \\
\hline & Ron & & furiously & loudly \\
\hline 10 & Harry & & madly & \\
\hline 11 & Hermione & & disapprovingly; matched away with her nose in the air & \\
\hline 13 & Harry & & desperately & \\
\hline \multirow[t]{2}{*}{14} & Hermione & & frantically & \\
\hline & Ron & & desperately & \\
\hline 15 & Harry & & stared hungrily & \\
\hline \multirow[t]{2}{*}{17} & Harry & & & whispered urgently \\
\hline & Hermione & briskly & grimly & \\
\hline \multirow[t]{3}{*}{18} & Harry & & desperately & \\
\hline & Hermione & & miserably & \\
\hline & Ron & & said in exasperation & \\
\hline \multirow[t]{2}{*}{19} & Hermione & & anxiously; watched in horror & \\
\hline & Ron & carefully & & \\
\hline \multirow[t]{2}{*}{20} & Harry & & & quickly \\
\hline & Hermione & & nervously & \\
\hline 21 & Harry & & anxiously & \\
\hline
\end{tabular}

The total number of positive, negative and neutral connotations ascribed to each character and their actions were counted and tabulated in the tables below:

Table 5. Comparison of the occurrences of adjectives among the characters

\begin{tabular}{|c|c|c|c|}
\hline \multirow{2}{*}{$\begin{array}{ll} & \text { Occurrences (\%) } \\
\text { Characters } & \end{array}$} & \multicolumn{3}{|l|}{ Adjectives } \\
\hline & Positive (\%) & Negative (\%) & Neutral (\%) \\
\hline Harry & 6.45 & 22.58 & 16.13 \\
\hline Hermione & 0 & 32.26 & 0 \\
\hline Ron & 0 & 16.13 & 6.45 \\
\hline Total & $31(100)$ & $31(100)$ & $31(100)$ \\
\hline
\end{tabular}

Table 6. Comparison of the occurrences of adverbs among the characters

\begin{tabular}{|c|c|c|c|}
\hline \multirow{2}{*}{$\begin{array}{ll}\text { Characters } & \text { Occurrences (\%) } \\
\end{array}$} & \multicolumn{3}{|l|}{ Adverbs } \\
\hline & Positive (\%) & Negative $(\%)$ & Neutral $(\%)$ \\
\hline Harry & 0 & 23.08 & 15.38 \\
\hline Hermione & 3.85 & 32.46 & 0 \\
\hline Ron & 3.85 & 11.54 & 3.85 \\
\hline Total & $26(100)$ & $26(100)$ & $26(100)$ \\
\hline
\end{tabular}

\subsection{Discussion}

\subsubsection{Harry (male)}

According to Stephens' schema, males are supposed to be physically strong; Harry, however, was depicted as "small and skinny" in Scenario 1 Line 1 (S1L1), and was often oppressed by his aunt's family, as shown from his glasses that were held together with a lot of Scotch tape because of all the times Dudley had punched him on the nose (S1L5-7) and Aunt Petunia cut his hair so short he was almost bald (S2L2\&3). In terms of knowledge, he was portrayed as powerless and uncompetitive who responded "I don't know, sir," thrice in the class (S6L7, 13, 19\&20) and begged his friend to "do something" when he needed to perform a spell (S18L7\&8). When family came into the picture, he became emotional. He had a powerful kind of ache inside him, half joy, half terrible 


\section{sadness (S15L3\&4).}

Other than that, Harry possessed mostly male traits throughout the novel. He was protective towards someone who needed to be protected. In S13 where Hermione was being trapped in the girls' bathroom with the troll, he fought the troll bravely. Again, he was shown to be protective as well as aggressive and violent in S7 when he helped Neville to get his Remembrall back from Malfoy. "Give it here, or I'll knock you off that broom!" (S7L13\&14). Besides, he often played the active leader role who gave orders and led. For example, when the gang was attacked by the troll, he commanded his friends to "Confuse it!" (S13L10) and "Come on, run, run!" (S13L15\&16).

In terms of processes and participants, it was shown that Harry had the most Material process and the actions were mostly directed to a Goal such as grabbed his broom (S7L4) and threw it as hard as he could against the wall (S13L11). He was portrayed as being aggressive with these rough and violent actions. Besides, his actions also showed the power of a leader, such as waved madly at the other three to follow him (S10L2), pulled the door open and they ran inside (S13L7\&8), etc. Although there are 10 occurrences where Harry was realized as the Goal, he was still the most dominant one among the trio as none of the occurrences were directed from either Hermione or Ron.

Harry possessed the most Mental processes as well but most were derived from his senses, i.e., how he perceived his surroundings. For example: Harry glanced at Ron, who looked as stumped as he was (S6L6); He heard screams and gasps of girls back on the ground (S7L11). There were only two instances where he was depicted as emotional, "he looked around anxiously" (S5L3\&4) when he first arrived at the school and "he stared hungrily back at them" (S15L1) when he first met his parents.

As for Relational process, many of the Attributes attached to Harry were about his physical appearance like "small and skinny" (S1L2), "pale" (S17L17), "his eyes were glittering" (S17L17), etc. There were also a number of Attributes referring to his emotions, such as Harry was relieved to see by his stunned face (S3L9); he'd never been more nervous (S5L7).

Lastly, Harry had the greatest number of positive and neutral adjectives and neutral adverbs.

\subsubsection{Hermione (female)}

Hermione was associated with strong male characteristics in the novel. She was active in engaging with people and self-introduced herself before the others did, "I'm Hermione Granger, by the way, who are you?" (S3L7\&8). She was very competitive in her studies who "learned all the course books by heart" (S3L6\&7) and "shot her hand into the air" (S6L6\&7) when the professor asked a question. Her aggressiveness was shown when she confronted the boys and tried to stop them from breaking the rules. "No! Madam Hooch told us not to move-you'll get us all into trouble" (S7L4\&5). She was also depicted as a girl with strong analytical skills, who often came out with a solution to a problem. In S21L26\&27 where Harry asked "You are sure which is which, aren 't you?" in regards to the answer of a riddle, she replied "Positive" confidently.

In terms of female characteristic, Hermione was obedient as she was afraid of breaking the rules and getting into troubles. Her advices and confrontations were always neglected which implied that she was powerless. For example, she warned the boys that "you mustn't go wandering around the school at night" (S8L5\&6) but Harry retorted that "it's really none of your business" (S8L8). She was portrayed as being vulnerable and helpless when she was attacked by the troll. She looked "as if she was about to faint" (S13L9) and "her mouth opened with terror" (S13L17). Moreover, she played more of a passive and submissive role in the trio, i.e., a helper or follower. For instance, she agreed to watch out for Snape as Harry told her so "Hermione, you'd better do that." (S17L3\&4) and followed Ron's command "Hermione, you go there instead of that castle." (S20L14\&15)

Hermione's emotional side was supported by her actions realized in Material and Mental process. Most of her actions in Material process were not directed to a Goal but were caused by her emotions instead, such as stomping up the stairs (S11L2) and she couldn't move (S12L17). On the other hand, the Mental processes that she was involved in also showed her being emotional. For example, Hermione wasn't going to give up that easily (S9L6\&7); she watched in horror as the two boys fought to pull the plant off them (S19L32).

In the scenarios where Hermione was realized as the Goal, she was depicted as being submissive and vulnerable in general, as shown in the following examples: Snape was still ignoring Hermione's quivering hand (S6L17); Harry ignored her (S7L5); the troll was advancing on her (S13L9\&10). When being realized as Phenomenon, Hermione was the projection of Harry's thinking. For example, Harry couldn't believe anyone (Hermione) could be so interfering (S9L4\&5); Harry thought she was probably right (S10L20\&21).

In terms of Relational process, Hermione was portrayed as competitive from the way she desired to answer the 
professor's questions. Hermione Granger was on the edge of her seat and looked desperate to start proving that she wasn't a dunderhead (S6L2\&3).

Lastly, Hermione had the greatest number of negative adjectives and adverbs and only one occurrence of positive adverb.

\subsubsection{Ron (male)}

Ron seemed to be the weakest character among the three. He was not as knowledgeable as Hermione, nor did he possess Harry's leadership. As a result, he was powerless in terms of knowledge who asked Hermione "What should we do?" (S14L6\&7) when Harry's broom was jinxed. His identity of a follower was supported in Material process as many of his actions were associated with Harry. For instance, Harry and Ron went back to the common room (S17L11); Ron followed right away (S19L21). When being realized as a Goal, most of the occurrences were directed from Harry as well, such as "Harry... waved at Ron to get his attention" (S19L7), "Harry turned to the others, 'Right, here's what we've got to do" (S16L1\&2), etc.

Throughout the novel, he was depicted as emotional with mostly anger and annoyance, such as exclaiming "You've got some nerve-" (S9L22) loudly when Hermione interfered with his outing, and "was in a very bad mood by the end of the class" (S12L6\&7) when Hermione corrected him from the wrong pronunciation. The Attributes attached to him in Relational process further supported his emotional side, such as " $a$ bit uncomfortable" (S12L12) for uneasiness and "purple in the face" (S22L1) for embarrassment.

Apart from that, he showed his protective and confident side when rescuing Hermione from the troll and playing chess. For example, he played as the leader who assigned respective roles in a chess game, "Harry, you take the place of that bishop, and Hermione, you go there instead of that castle" (S20L14\&15). Moreover, his actions were independent and contained a Goal in these scenarios: Ron pulled out his own wand (S13L28); he walked up to a black knight (S20L5\&6).

In terms of adjectives and adverbs, Ron had a few positive, negative and neutral connotations ascribed to him.

\section{Analysis and Interpretation of Findings}

\subsection{Portrayal of Main Characters}

From the portrayal of the main characters, it is shown that the characters did not follow the traditional stereotypical traits of male and female, in which males are strongly aggressive, competent and taking initiative while females are more dependent, lacking competence and needing help and protection (Frasher \& Walker, 1972). In Harry Potter and the Philosopher's Stone (Rowling, 1997), Harry and Ron were not as aggressive as Hermione, nor were they as competent as Hermione in terms of knowledge. Hermione, on the other hand, offered help more often than receiving help from the others. The analysis had somehow reflected Diekman and Murnen's finding that non-sexist books do not show male characters possessing female gender roles but only portray female characters adopting masculinity, and that female stereotypic personality is shown similarly in both sexist and non-sexist books (Diekman \& Murnen, 2004). This could be seen from Hermione being more vulnerable than the boys and seemingly requiring more protection. Like the other females, she was also more caring who often provided emotional support to others. On the other hand, although Harry and Ron were portrayed as being emotional, their emotions were often associated with frustration and irritation, less on sorrow and misery.

It is also interesting to note how Hermione was not favored by the boys until they saved her from the troll. In the beginning of the novel, she was portrayed as a bothersome know-it-all who interfered with their business. It is worth asking whether it was her cleverness that caused Harry and Ron to dislike her and not the strength and competence that the boys did not possess. The boys befriended her only after they rescued her from the troll, where she was depicted as a vulnerable girl. This could be seen as the point where Hermione started to display stereotypical female gender roles of being weak and needing help and protection. In other words, she had to conform to the norms in order to be desirable and be accepted, which corresponded to Stephens' statement that if a female subverts the stereotypes and shows signs of masculinity, she is often being compelled to revert back to the norm (1996; as cited in Tsatsa, 2013).

\subsection{SFL Transitivity Analysis}

The transitivity analysis revealed that, in general, the male characters performed more practical actions than the female character, i.e., their actions had an impact on the Goals. The Material processes showed that the actions performed by Harry and Ron caused an effect while many of Hermione's actions were resulted from her emotions. In terms of being realized as a Goal, Harry was more likely to be a leader in the trio, while the other two played the role of followers or helpers. From the analysis of Mental processes, Harry perceived and thought 
more than the other two. On the other hand, Hermione was characterized as being emotional. In regards to Relational process, Harry and Ron were more emotional while Hermione was shown as being competitive. The findings of Material and Mental processes were slightly different from Gallardo's findings that males act more whereas females perceive more (Gallardo, 2006), because in this novel, while Harry was the one who acted more, all three characters were relatively emotional. Also, in contrast to Gallardo's finding in Relational processes that "the female sees herself as inferior to the male" (2006, p. 760), Hermione was very confident with herself in terms of her knowledge and intelligence.

On a side note, Ron had the least processes ascribed to him, suggesting that he had the lowest visibility compared to Harry and Hermione. This confirmed the finding that he was the weakest character among the three; he usually acted and perceived with Harry or Hermione, which implied that he was a follower or helper and was passive.

\subsection{Lexical Choices}

From Table 5 and 6, it was shown that most of the adjectives and adverbs ascribed to the characters and their actions had negative connotations, with Hermione having a higher number of occurrences in both figures. This further substantiated the findings of past researches that females demonstrate traits that are viewed as less desirable in general (Dino, Barnett, \& Howard, 1984; Spence \& Helmreich, 1980). In fact, many of the negative connotations were related to emotions, implying that Hermione was more emotional than the other two.

On a side note, the negative adjectives and adverbs of Hermione and Ron were more detailed than Harry's, which gave the readers a deeper impression on these descriptions. For example, Hermione was described sarcastically with adjectives like "her hand stretching toward the dungeon ceiling" (S6L19) and adverbs like "stretched her hand as high into the air as it would go without her seat" (S6L10\&11). Ron was also portrayed to go "purple in the face" (S22L1) and looked "like a radish with a bad sunburn" (S22L2). On the other hand, the adjectives and adverbs used to describe Harry were brief and more succinct like "embarrassed" and "nervously". Therefore, it was assumed that the author intended to make the negative connotations ascribed to Harry to go less noticed.

\section{Conclusions}

Based on the analysis and discussion, it is difficult to conclude whether the author of Harry Potter and the Philosopher's Stone, Rowling had promoted or challenged the gender stereotypes because the three main characters portrayed not only masculine but also feminine traits. If ever there was a difference, it was only a variation in the masculine-feminine continuum, in which the characters were gendered, by choice or by societal compulsion. For example, although Harry possessed a strong masculinity, he also showed femininity in terms of being powerless, vulnerable, emotional, etc. Similarly, even though there were times that Hermione was shown as more competent and aggressive than the boys, she was also portrayed as obedient, submissive and passive; while Ron's masculinity (powerful and aggressive) was combined with femininity (emotional and submissive). This concurs with the findings of Tsatsa (2013) who stated that these three main characters show both male and female characteristics. As proven in this paper's analysis and discussion, the three main characters' gender roles are complex and not static.

In terms of visibility in the novel, Harry and Hermione had similar numbers of processes ascribed to them while Ron was involved in the least processes, which implied that he was the weakest character in the trio even though he was a male. This had reinforced previous studies' argument that there is a tendency towards more egalitarian roles in the portrayal of characters (Tognoli et al., 1994; Oskamp et al., 1996), seeing that the visibility of female character in this novel had increased in comparison with previous studies of children literature.

Therefore, there is no definite answer to whether Rowling's writing was stereotypical because she broke the stereotypes in some instances while conforming to them in some others. In this novel, boys were allowed to be weak while girls could be smarter than boys. At the same time, boys were still the leaders while girls needed protection.

This paper studied only the three main characters of the first book of Harry Potter series. For further research, the corpus of this paper can be expanded to all the seven books of the series as well as the other characters in order to establish a stronger judgment whether Rowling's writing contained gender stereotypes or not. Moreover, aside from the three main processes, the other three minor processes should also be examined to gain a more comprehensive understanding of Harry Potter characters' roles, processes and circumstances.

\section{References}

Anderson, D. A., \& Hamilton, M. (2005). Gender role stereotyping of parents in children's picture books: The 
invisible father. Sex Roles, 52(3-4), 145-151. https://doi.org/10.1007/s11199-005-1290-8

Ashmore, R. D., \& Del Boca, F. K. (1979). Sex stereotypes and implicit personality theory: Toward a Cognitive-Social psychological conceptualization. Sex Roles, 5(2), 219-248. https://doi.org/10.1007/BF00287932

Barnett, M. A. (1986). Sex bias in the helping behavior presented in children's picture books. The Journal of Genetic Psychology, 147(3), 343-351. https://doi.org/10.1080/00221325.1986.9914508

Berk, L. E. (2003). Child development (6th ed.). London: Pearson Education, Inc.

Block, J. H. (1973). Conceptions of sex-role: Some cross-cultural and longitudinal perspectives. American Psychologist, 28(6), 512-526. https://doi.org/10.1037/h0035094

Bloor, T., \& Bloor, M. (2004). The functional analysis of English: A Hallidayan approach (2nd ed.). New York: Oxford University Press Inc. https://doi.org/10.4324/9780203774854

Butler, J. (1999). Gender trouble. London: Routledge.

Calio, V., Frohlich, T. C., \& Hess, A. E. M. (2014, May 18). 10 best-selling products of all time. USA Today. Retrieved from http://www.usatoday.com

Cook, R., \& Cusack, S. (2011). Gender stereotyping: Transnational legal perspectives. Philadelphia, Pennsylvania: University of Pennsylvania Press. https://doi.org/10.9783/9780812205923

Creswell, J. W. (2012). Educational research: Planning, conducting, and evaluating quantitative and qualitative research (4th ed.). Boston: Pearson Education, Inc.

Crystal, D., \& McLachlan, E. (2004). Rediscover grammar. Harlow: Longman.

Diekman, A. B., \& Murnen, S. K. (2004). Learning to be little women and little men: The inequitable gender equality of nonsexist children's literature. Sex Roles, 50(5-6), 373-385. https://doi.org/10.1023/B:SERS.0000018892.26527.ea

Dino, G. A., Barnett, M. A., \& Howard, J. A. (1984). Children's expectations of sex differences in parents' responses to sons and daughters encountering interpersonal problems. Sex Roles, 11(7-8), 709-717. https://doi.org/10.1007/BF00288122

Fairclough, N. (1995). Critical Discourse Analysis: The Critical Study of Language. London: Longman.

Flood, A. (2011, May 6). Study finds huge gender imbalance in children's literature. The Guardian. Retrieved from http://www.theguardian.com/uk

Frasher, R., \& Walker, A. (1972). Sex roles in early reading textbooks. The Reading Teacher, 741-749.

Gallardo, B. C. (2006). Analysis of a literary work using systemic-functional grammar (pp. 735-762). Thirty-third International Systemic Functional Congress Proceedings, Brazil.

Gharbavi, A., \& Mousavi, S. A. (2012). A content analysis of textbooks: Investigating gender bias as a social prominence in Iranian High School English textbooks. English Linguistics Research, 1(1), 85-93. https://doi.org/10.5430/elr.v1n1p42

Golombok, S., \& Fivush, R. (1994). Gender development. Cambridge, United Kingdom: Cambridge University Press.

Halliday, M. A. K. (1970). Language structure and language function. In J. Lyons (Ed.), New horizons in linguistics (pp. 140-165). London: Penguin.

Halliday, M. A. K. (1994). An introduction to functional grammar (2nd ed.). London: Edward Arnold.

Jacobson, M. B. (1979). A rose by any other name: Attitudes toward feminism as a function of its label. Sex Roles, 5(3), 365-371. https://doi.org/10.1007/BF00287404

Kortenhaus, C. M., \& Demarest, J. (1993). Gender role stereotyping in children's literature: An update. Sex Roles, 28(3-4), 219-232. https://doi.org/10.1007/BF00299282

Oskamp, S., Kaufman, K., \& Wolterbeek, L. A. (1996). Gender role portrayals in preschool picture books. Journal of Social Behavior and Personality, 11(5), 27-39.

Rowling, J. K. (1997). Harry Potter and philosopher's stone. London: Bloomsbury.

Sörensen, J. (2014). Archetypes and stereotypes in JK Rowling's Harry Potter series. Undergraduate Thesis. University of Gothenburg, Gothenburg, Sweden. Retrieved from 
https://gupea.ub.gu.se/bitstream/2077/35062/1/gupea_2077_35062_1.pdf

Spence, J. T., \& Helmreich, R. L. (1980). Masculine instrumentality and feminine expressiveness: Their relationships with sex role attitudes and behaviors. Psychology of Women Quarterly, 5(2), 147-163. https://doi.org/10.1111/j.1471-6402.1980.tb00951.x

Stephens, J. (1996). Gender, genre and children's literature. Signal, 79, 17-30.

Tsatsa, F. (2013). Gender roles in Harry Potter. Stereotypical or unconventional? Undergraduate Thesis. University of Gothenburg, Gothenburg, Sweden. Retrieved from https://gupea.ub.gu.se/bitstream/2077/33244/1/gupea_2077_33244_1.pdf

Weitzman, L. J., Eifler, D., Hokada, E., \& Ross, C. (1972). Sex-role socialization in picture books for preschool children. American Journal of Sociology, 77(6), 1125-1150. https://doi.org/10.1086/225261

\section{Appendix A}

\section{Example of Extracted Scenes from the Corpus}

\section{Scenario 2 (p. 23)}

1 Once, Aunt Petunia, tired of Harry coming back from the barbers looking as though he hadn't been at all, had taken a pair of kitchen scissors and cut his hair so short he was almost bald except for his bangs, which she left "to hide that horrible scar." Dudley had laughed himself silly at Harry, who spent a

5 sleepless night imagining school the next day, where he was already laughed at for his baggy clothes and taped glasses. Next morning, however, he had gotten up to find his hair exactly as it had been before Aunt Petunia had sheared it off. He had been given a week in his cupboard for this, even though he had tried to explain that he couldn't explain how it had grown back so

10 quickly. Another time, Aunt Petunia had been trying to force him into a revolting old sweater of Dudley's (brown with orange puff balls). The harder she tried to pull it over his head, the smaller it seemed to become, until finally it might have fitted a hand puppet, but certainly wouldn't fit Harry. Aunt Petunia had decided it must have shrunk in the wash and, to his great relief, Harry wasn't punished.

\section{Example of Analysis of Process and Participants}

\section{Scenario 12 (p. 127)}

"You're saying it wrong," Harry heard Hermione snap. "It's Wing-gar-dium Levi-osa, make the 'gar' nice and long." "You do it, then, if you're so clever," Ron snarled.

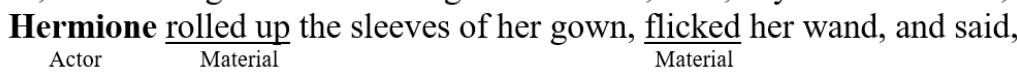
"Wingardium Leviosa!" Their feather rose off the desk and hovered about four feet above their heads. "Oh, well done!" cried Professor Flitwick, clapping. "Everyone see here, Miss Granger's done it!" Ron was in a very bad mood by the end of the class. "It's no wonder no one can stand her," he said to Harry as they pushed their way into the crowded corridor, "she's a nightmare, honestly." Someone knocked into Harry as they hurried past him. It was Hermione. Harry caught a glimpse of her face - and was startled to see that she was in tears. "I think she heard you." "So?" said Ron, but Carrier Relational Attribute

he looked a bit uncomfortable. "She must've noticed she's got no friends." Carrier Relational Attribute 


\section{Copyrights}

Copyright for this article is retained by the author, with first publication rights granted to the journal.

This is an open-access article distributed under the terms and conditions of the Creative Commons Attribution license (http://creativecommons.org/licenses/by/4.0/). 